\title{
Effect of different dietary inclusion levels of whole raw soyabean on ruminal fermentation and nutrient utilization in Nelore steers
}

\author{
N.R.B. Cônsolo ${ }^{1,4}$, J.R. Gandra ${ }^{2}$, R. Gardinal', J.E. Freitas Júnior ${ }^{3}$, C.S. Takiya ${ }^{1}$, F.P. Rennó ${ }^{1}$ \\ and A.S.C. Pereira ${ }^{1}$ \\ 1 University of São Paulo, School of Veterinary Medicine, Department of Animal Science \\ Duque de Caxias Norte 225, 13635-900 Pirassununga, São Paulo, Brazil \\ 2 University of Grande Dourados, School of Agrarian Sciences, Department of Animal Sciences, \\ km 12, 79804-970 Dourados, Mato Grosso do Sul, Brazil \\ ${ }^{3}$ University of Bahia, School of Veterinary Medicine, Department of Animal Sciences, \\ Adhemar de Barros, 40170-110 Salvador, Bahia, Brazil
}

KEY WORDS: beef cattle, Nelore, digestibility, metabolites, soyabean

Received: 29 August 2016

Revised: $\quad 20$ June 2017

Accepted: 6 December 2017

${ }^{4}$ Corresponding author:

e-mail: nara.consolo@hotmail.com

\begin{abstract}
The aim of this study was to evaluate the effects of increasing level of whole raw soyabean (WRS) in the diet of Nelore steers on nutrient intake and digestibility, ruminal fermentation, nitrogen utilization and blood profile. Twelve steers (2-year-old; $400 \pm 28.5 \mathrm{~kg}$ body weight) were used in a triple $4 \times 4$ Latin square design. The animals were randomly assigned to the following treatments: control (WRS0; without WRS), and diets containing 80 (WRS8), 160 (WRS16) and 240 (WRS24) $\mathrm{g} \cdot \mathrm{kg}^{-1}$ DM of WRS in the diet. The steers were fed diet with 40:60 forage:concentrate ratio. Ingredients, refusals and faeces were sampled to determine total tract apparent digestibility. Samples of ruminal fluid were collected on day 19 before the morning feeding and 2, 4, 6, 10 and $12 \mathrm{~h}$ after the morning feeding for $\mathrm{pH}$, ammonia and short-chain fatty acid analyses. Spot urine samples were obtained on day 20 for nitrogen balance analysis. Blood samples were collected on day 21 for protein and energy metabolism analyses. Inclusion of WRS decreased DM and non-fibre carbohydrate intake, increased ether extract intake, affected ruminal $\mathrm{pH}$, ammonia and acetate concentrations, and linearly increased serum high density lipoprotein and total cholesterol contents. Nitrogen excretion in urine increased linearly with WRS inclusion. Addition of WRS exerted a quadratic effect on nitrogen balance. In conclusion, WRS inclusion into the diet of Nelore steers did not change nutrient digestibility, promoted few changes in rumen metabolism and blood parameters, and was not detrimental to digestive functions.
\end{abstract}

\section{Introduction}

Sources of unsaturated fatty acids (FA) have been used in ruminant diets to improve dietary energy density. Among different fat sources available to feed ruminants, soyabean grain stands out with its high availability, low cost and high nutritional value (Barletta et al., 2016). Currently, Brazil is the second highest soyabean producer in the world with $95 \mathrm{mln}$ t produced in 2014/2015 from total cultivated area of $31.5 \mathrm{mln}$ ha (Agrianual, 2016). The soyabean grain is used as a protein and fat source with its high neutral detergent fibre (NDF) digestibility and approximate composition of $393 \mathrm{~g} \cdot \mathrm{kg}^{-1}$ of crude 
protein (CP), $192 \mathrm{~g} \cdot \mathrm{kg}^{-1}$ of fat and $950 \mathrm{~g} \cdot \mathrm{kg}^{-1}$ of total digestive nutrients (Valadares Filho et al., 2006; Barletta et al., 2016).

Fat supplementation may alter ruminal fermentation and decrease NDF digestibility (Jenkins, 1993; Howlett et al., 2003). These features can be attributed to the toxic effects of polyunsaturated FA on ruminal protozoa and bacteria (Jenkins, 1993; Howlett et al., 2003). However, depending on the type of FA, the amount of unsaturation, and how it gets into the rumen, free or partially protected, this effect can be maximized or minimized (Bettero et al., 2013). FA from oilseeds, such as soyabean grain, are slowly released into the rumen, consequently avoiding unsaturated FA accumulation and impairment of ruminal fibre degradation (Bettero et al., 2013).

Data on feeding whole raw soyabean (WRS) to animals and its effects on nutrient digestion and ruminant performance are scarce. Barletta et al. (2016) examined high levels of WRS $\left(240 \mathrm{~g} \cdot \mathrm{kg}^{-1}\right.$ diet DM) in the diets of Holstein dairy cows and reported a linear decrease in DM intake (DMI) as WRS was included; however, milk production (3.5\% of fat) was not affected. Venturelli et al. (2015) included WRS $\left(0,90,180\right.$ and $270 \mathrm{~g} \cdot \mathrm{kg}^{-1}$ diet DM $)$ in the diet of lactating cows and did not find any adverse effect on milk production. The same authors also reported no adverse effect of WRS anti-nutritional factors, such as trypsin inhibitor and urease, on dairy cow health and production (Venturelli et al., 2015; Barletta et al., 2016). In addition, de Almeida et al. (2016) fed dairy cows $120 \mathrm{~g} \cdot \mathrm{kg}^{-1}$ of WRS and reported a decrease in DMI as the grain was included and an increase in ether extract (EE) intake, with no change in milk production and composition. However, Howlett et al. (2003) fed steers diets containing 15\% cottonseeds or $15 \%$ or $25 \%$ soyabeans on DM basis and reported that total-tract NDF digestibilities were the lowest for the oilseed treatments, suggesting that the negative effect of oils on the ruminal environment was not overcome postruminally. Nevertheless, in very few prior studies the effect of WRS on ruminal environment has been investigated. Thus, the aim of the study was to evaluate the effects of increasing levels of WRS in the diet of Nelore steers on nutrient intake and digestibility, ruminal fermentation, nitrogen utilization and blood profile.

\section{Material and methods}

All procedures were conducted in accordance with the Institutional Animal Care and Use Committee Guidelines of the University of São Paulo (Brazil).

\section{Experimental site, cattle and diet}

The experiment was conducted in the Dairy Cattle Research Laboratory at the University of São Paulo in Pirassununga, São Paulo in southeast Brazil. Twelve Nelore steers, fitted with rumen cannulas, 24 months of age $(400 \pm 28.5 \mathrm{~kg}$ of live weight) were used in a triple $4 \times 4$ Latin square design experiment. The animals were housed for 21 days during each experimental period (14 days of adaptation and 7 days of data collection), in total 84 days. The steers were randomly assigned to the following diets (Table 1): control (WRS0; no addition of WRS), diets containing 80 (WRS8), 160 (WRS16) or 240 (WRS24) $\mathrm{g} \cdot \mathrm{kg}^{-1}$ of WRS in diet (DM basis). The animals were allocated in individual pens $\left(17.5 \mathrm{~m}^{2}\right)$ and fed once a day at 8:00 diet with a 40:60 forage:concentrate ratio

Table 1. Ingredients and chemical composition of experimental diets

\begin{tabular}{|c|c|c|c|c|}
\hline \multirow{2}{*}{ Indices } & \multicolumn{4}{|l|}{ Diet $^{1}$} \\
\hline & WRSO & WRS8 & WRS16 & WRS24 \\
\hline \multicolumn{5}{|l|}{ Composition, $\%$ of DM } \\
\hline maize silage ${ }^{2}$ & 40.0 & 40.0 & 40.0 & 40.0 \\
\hline ground maize & 43.7 & 41.9 & 41.0 & 33.7 \\
\hline soyabean meal & 13.4 & 6.8 & - & - \\
\hline whole raw soyabean & - & 8.0 & 16.0 & 24.0 \\
\hline urea & 0.6 & 0.6 & 0.6 & - \\
\hline ammonium sulphate & 0.2 & 0.2 & 0.2 & 0.1 \\
\hline limestone & 0.1 & 0.1 & 0.1 & 0.1 \\
\hline mineral premix ${ }^{3}$ & 2.0 & 2.0 & 2.0 & 2.0 \\
\hline salt & 0.1 & 0.1 & 0.1 & 0.1 \\
\hline \multicolumn{5}{|c|}{ Chemical composition, $\mathrm{g} \cdot \mathrm{kg}^{-1}$} \\
\hline dry matter & 640 & 644 & 648 & 651 \\
\hline organic matter & 966 & 966 & 966 & 962 \\
\hline crude protein & 134 & 131 & 132 & 133 \\
\hline neutral detergent fibre & 293 & 296 & 300 & 305 \\
\hline acid detergent fibre & 155 & 160 & 164 & 174 \\
\hline non-fibre carbohydrate & 486 & 484 & 483 & 457 \\
\hline ether extract & 20 & 35 & 49 & 64 \\
\hline ash & 25 & 25 & 26 & 31 \\
\hline net energy, Mcal $\cdot \mathrm{kg}^{-1}$ & 19 & 20 & 21 & 22 \\
\hline \multicolumn{5}{|l|}{$\mathrm{g} \cdot 100 \mathrm{~g}^{-1}$ of fatty acids } \\
\hline meristic & 0.3 & 0.2 & 0.2 & 0.2 \\
\hline palmitic & 10.7 & 11.1 & 11.6 & 12.2 \\
\hline stearic & 3.3 & 3.3 & 3.4 & 3.5 \\
\hline oleic & 21.7 & 21.1 & 20.5 & 20.2 \\
\hline linoleic & 48.3 & 48.2 & 48.2 & 48.8 \\
\hline linolenic & 5.1 & 5.1 & 5.2 & 5.2 \\
\hline total unsaturated & 75.1 & 74.4 & 73.9 & 74.2 \\
\hline
\end{tabular}

${ }^{1}$ levels of whole raw soyabean (WRS) in the diets, $\mathrm{g} \cdot \mathrm{kg}^{-1} \mathrm{DM}$ : WRS0 0, WRS8 80, WRS16 160, WRS24 $240 ;{ }^{2}$ chemical composition, \%: DM 26.19, CP 9.18, NDF 57.72, ADF 36.63, NFC 24.67, based on composite samples per period; ${ }^{3}$ supplied per kg of product: $\mathrm{g}$ : Ca 180 , P 90, Na 120, Mg 20, S 15; mg: Cu 100, Zn 2500, Mn 1000, I 80, Co 100 , Se 20 
(DM basis; Table 1). The diets were formulated to reach the same crude protein level $(13 \%)$ and to meet the NRC (2000) requirements in terms of an average daily gain $(A D G)$ of $1.2 \mathrm{~kg} \cdot \mathrm{d}^{-1}$

\section{Sample collection and chemical analyses}

The ingredients and refusals of each experimental diet were weighed daily to estimate individual intake. Diets were offered ad libitum, DMI was measured daily by weighing the offered feed and refusals. As a result the amount of feed was adjusted daily to allow for min. 5\% refusals. Diet ingredients and refusals were sampled weekly, pooled according the period, stored in plastic bags and kept at $-20{ }^{\circ} \mathrm{C}$. The samples were dried in a $55{ }^{\circ} \mathrm{C}$ forcedair oven for $72 \mathrm{~h}$ and ground to pass through a $1-\mathrm{mm}$ screen (Wiley mill, Arthur H. Thomas, Philadelphia, PA, USA) and then chemical composition and nutrients intake were estimated. Faeces were sampled directly from the rectum two times a day from day 15 to day of each experimental period, always before the morning feeding. For determination of apparent digestibility of total DM and nutrients, the total quantity of faecal DM excreted was estimated by the concentration of indigestible acid-detergent fibre (iADF; Casali et al., 2008). Diet ingredients, refusals and faeces samples were analysed according to AOAC International (2000) for DM (method 930.15), crude protein $(\mathrm{N} \times 6.25$; method 984.13), ether extract (method 920.39), acid detergent fibre and lignin (method 973.18) and ash (method 942.05). Neutral detergent fibre and protein were analysed according to Van Soest et al. (1991) using $\alpha$-amylase without sodium sulphite.

To estimate FA profile of diets, the extraction process was conducted according to Folch et al. (1957); the separated fat was methylated and the methyl esters were formed according to Kramer et al. (1997). Fatty acids profile was measured with gas chromatograph (Shimadzu GC 2010 with automatic injection, Shimadzu Corporation, Kyoto, Japan) using capillary column SP-2560 (length $100 \mathrm{~m}$, i.d. $0.25 \mathrm{~mm}$, film thickness $0.02 \mathrm{~mm}$; Supelco, Bellefonte, PA, USA). Oven temperature programme started at $70{ }^{\circ} \mathrm{C}$ held for $4 \mathrm{~min}$, then increased to $175{ }^{\circ} \mathrm{C}$ at a rate of $13{ }^{\circ} \mathrm{C} \cdot \min ^{-1}$ and was held for $27 \mathrm{~min}$, then increased to $215^{\circ} \mathrm{C}$ at a rate of $4{ }^{\circ} \mathrm{C} \cdot \mathrm{min}^{-1}$ and was held for $31 \mathrm{~min}$. Hydrogen was used as carrier gas with flux of $40 \mathrm{~cm} \cdot \mathrm{s}^{-1}$ as previously described by Barletta et al. (2016). During the process of FA identification, four standards were used: standard C4-C24 FAs (Supelco ${ }^{\circledR}$ TM 37, Bellefonte, PA, USA), vaccenic acid C18:1 trans-11 (V038-1G; Sigma-Aldrich, St. Louis, MO, USA),
CLA C18:2 trans-10, cis-12 (UC-61M 100MG, NU-CHEK-PREP ${ }^{\circledR}$, Elysian, MN, USA) and CLA C18:2 cis-9, trans-11 (UC-60M 100MG NU-CHEKPREP $^{\circledR}$, Elysian, MN, USA).

\section{Ruminal fermentation}

Samples of ruminal fluid were collected and filtered through the ruminal cannulas on day 19 of each period before morning feeding and 2, 4, 6, 10 and $12 \mathrm{~h}$ after morning feeding. Immediately after collection, the $\mathrm{pH}$ of the ruminal fluid was determined using a potentiometer (MB-10, Marte, Sapucaí, Brazil) as previously described by de Almeida et al. (2016). For ammonia nitrogen $\left(\mathrm{NH}_{3}-\mathrm{N}\right)$ concentration measurements, the ruminal fluid was mixed with sulphuric acid $\left(0.5 \mathrm{~mol} \cdot 1^{-1} \mathrm{H}_{2} \mathrm{SO}_{4}\right)$ and stored at $-20{ }^{\circ} \mathrm{C}$ for posterior analysis with the salicylic acid method according to Foldager (1977). Short-chain FA (SCFA) concentrations were analysed by mixing the ruminal fluid aliquots with metaphosphoric acid $\left(0.25 \mathrm{~mol} \cdot 1^{-1}\right.$ $\mathrm{HPO}_{3}$ ) and then centrifuging it at $7000 \mathrm{~g}$ at $4{ }^{\circ} \mathrm{C}$; the supernatant was stored at $-20^{\circ} \mathrm{C}$ for posterior analysis according to Erwin et al. (1961). Ruminal SCFAs were measured with gas chromatograph with parameters as described above.

\section{Nitrogen balance and microbial protein synthesis}

The nitrogen balance and microbial protein synthesis were determined according to methodology described and validated by Rennó et al. (2008). Urine spot samples $(50 \mathrm{ml})$ were obtained from all steers on day 20 of each experimental period, $4 \mathrm{~h}$ after morning feeding. A sample of pure urine was stored at $-20{ }^{\circ} \mathrm{C}$ for further analysis of total nitrogen, urea and creatinine contents. Nitrogen balance was calculated by subtracting from the total nitrogen intake $(\mathrm{g})$ the values of nitrogen in the urine and faeces, with the values for retained nitrogen in $g$ and \% of total nitrogen. Creatinine concentrations were determined using commercial kits (Laborlab ${ }^{\circledR}$, Guarulhos, Brazil) and kinetic colorimetric enzymatic reactions (SBA-200, Modern Laboratory Equipment Company, Barueri, Brazil).

The microbial protein synthesis was determined by colorimetry, according to Chen and Gomes (1992). The daily urinary excretion of creatinine was estimated based on the proposition of $24.05 \mathrm{mg} \cdot \mathrm{kg}^{-1}$ of live weight. Thus, using the average daily excretion of creatinine and creatinine concentration $\left(\mathrm{mg} \cdot \mathrm{dl}^{-1}\right)$ in spot urine samples, the total daily urine volume was estimated, in $1 \cdot$ animal $^{-1} \cdot \mathrm{d}^{-1}$, for the calculation of nitrogen balance (Chizotti et al., 2008). The ruminal synthesis of nitrogen compounds and microbial 
nitrogen (Nmic) was calculated based on absorbed purine derivatives using the equation (Rennó et al., 2008):

$$
\mathrm{Nmic}=(70 \times \mathrm{PDabs}) /(0.83 \times 0.134 \times 1000)
$$

where: 70 - nitrogen purine derivative content $\left(\mathrm{mg} \mathrm{N} \cdot \mathrm{mol}^{-1}\right), 0.134$ - ratio of nitrogen purine derivatives per Nmic (Valadares et al., 1999), 0.83 - intestinal digestibility of microbial purines.

\section{Blood analysis}

Blood samples were collected on day 21 by jugular venepuncture prior to the morning feeding. Blood samples were collected into $10 \mathrm{ml}$ tubes (BD Vacutainer, São Paulo, SP, Brazil) without anticoagulant. Blood samples were centrifuged at $3000 \mathrm{~g}$ at $4{ }^{\circ} \mathrm{C}$ for $20 \mathrm{~min}$ to obtain the serum and frozen at $-20{ }^{\circ} \mathrm{C}$ for further analysis of the serum glucose, total protein, albumin, serum urea and cholesterol content. Serum parameters were analysed colorimetrically according to standard procedures using commercially available diagnostic kits (Laborlab Laboratories, Garulhos, SP, Brazil) for automatic biochemistry analyses (SBA-200, Modern Laboratory Equipment Company, Barueri, Brazil).

\section{Statistical analysis}

The data were analysed with the use of SAS software (version 9.1.3; SAS Institute Inc., Cary, NC, USA). Firstly, the normality of residuals and the homogeneity of variances were verified using the UNIVARIATE procedure. Then the data were analysed according to the following model:

$$
\mathrm{Y}_{\mathrm{ijky}}=\mu+Q_{i}+\mathrm{A}_{\mathrm{j}}+\mathrm{P}_{\mathrm{y}}+\mathrm{T}_{\mathrm{k}}+\mathrm{e}_{\mathrm{ijky}}
$$

where: $\mathrm{Y}_{\mathrm{ijky}}$ - dependent variable, $\mu$ - general mean, $Q_{i}$ - effect of square, $\mathrm{A}_{\mathrm{j}}$ - animal's effect, $\mathrm{P}_{\mathrm{y}}$ - effect of period, $\mathrm{T}_{\mathrm{k}}-$ effect of treatment, $\mathrm{e}_{\mathrm{ijky}}$ - error.

Polynomial regression analysis was performed using the MIXED procedure (SAS Software, SAS Institute Inc., Cary, NC, USA). Results of repeated measures were subjected to three covariance structures: symmetric compound, first-order autoregressive and unstructured. The covariance structure in each model that demonstrated the smallest Schwarz Bayesian criterion was considered the most desirable and reliable analysis. Significant level was set at $P<0.05$.

\section{Results}

\section{Nutrient intake and total tract digestibility}

The inclusion of WRS linearly decreased DM, organic matter and non-fibre carbohydrate intake $(P=0.04, P=0.03$ and $P=0.014$, respectively of the diets; Table 2). In the control group (without WRS inclusion) DM and organic matter intakes were about $10.5 \%$ greater than in WRS16 group and the non-fibre carbohydrate intake was $23.8 \%$ greater than in animals from WRS8. Also, the inclusion of WRS linearly increased EE intake $(P=0.014$; Table 2). A quadratic effect $(P=0.029)$ was observed for $\mathrm{CP}$ intake, with lower CP intake in steers fed diet with $160 \mathrm{~g} \cdot \mathrm{kg}^{-1}$ WRS addition on the DM-basis diet. Total tract EE digestibility exerted a quadratic effect with WRS inclusion as lower digestibility was observed with $160 \mathrm{~g} \cdot \mathrm{kg}^{-1}$ WRS inclusion into the DM-basis diet. However, the WRS did not change the DM, organic matter, CP, NDF and non-fibre carbohydrate total tract apparent digestibility.

\begin{tabular}{|c|c|c|c|c|c|c|c|}
\hline \multirow{2}{*}{ Indices } & \multicolumn{4}{|l|}{ Diet $^{1}$} & \multirow{2}{*}{ SEM } & \multicolumn{2}{|c|}{$P$-value ${ }^{2}$} \\
\hline & WRSO & WRS8 & WRS16 & WRS24 & & $\mathrm{L}$ & $Q$ \\
\hline \multicolumn{8}{|c|}{ Nutrients intake, $\mathrm{kg} \cdot$ animal $^{-1} \cdot \mathrm{d}^{-1}$} \\
\hline dry matter & 8.88 & 8.33 & 7.95 & 8.11 & 0.22 & 0.040 & 0.224 \\
\hline organic matter & 8.65 & 8.11 & 7.74 & 7.86 & 0.21 & 0.030 & 0.238 \\
\hline crude protein & 1.20 & 1.13 & 1.03 & 1.31 & 0.03 & 0.276 & 0.029 \\
\hline ether extract & 0.18 & 0.32 & 0.45 & 0.59 & 0.02 & 0.014 & 0.958 \\
\hline neutral detergent fibre & 2.60 & 2.35 & 2.38 & 2.40 & 0.06 & 0.589 & 0.129 \\
\hline non-fibre carbohydrate & 4.66 & 4.30 & 3.86 & 3.55 & 0.12 & 0.014 & 0.859 \\
\hline \multicolumn{8}{|c|}{ Total tract digestion, $\mathrm{g} \cdot \mathrm{kg}^{-1}$ diet } \\
\hline dry matter & 662 & 666 & 644 & 655 & 6.40 & 0.448 & 0.748 \\
\hline organic matter & 686 & 687 & 664 & 676 & 6.13 & 0.298 & 0.655 \\
\hline crude protein & 709 & 700 & 696 & 723 & 7.52 & 0.594 & 0.256 \\
\hline ether extract & 862 & 839 & 836 & 891 & 6.61 & 0.124 & 0.001 \\
\hline neutral detergent fibre & 570 & 532 & 501 & 527 & 13.10 & 0.148 & 0.196 \\
\hline non-fibre carbohydrate & 751 & 771 & 742 & 739 & 8.14 & 0.335 & 0.447 \\
\hline
\end{tabular}

Table 2. Nutrient intake and total tract digestion of Nelore steers fed diets with increasing level of whole raw soyabean

${ }^{1}$ see Table $1 ;{ }^{2}$ linear $(L)$ and quadratic $(Q)$ effect; SEM - standard error of mean 


\section{Rumen and blood variables}

There was observed a quadratic effect on ruminal pH $(P=0.02)$, ammonia $(P=0.04)$, acetate $(P=0.02)$ and total SCFA $(P=0.03)$ concentrations as WRS was included (Table 3). The highest $\mathrm{pH}$ and the lowest ammonia concentration were found with $160 \mathrm{~g} \cdot \mathrm{kg}^{-1}$ WRS inclusion on the DM-basis diet. A quadratic effect was observed for total nitro-gen intake $(P=0.02)$, absorbable nitrogen $(P=0.006)$ and retained nitrogen $(P=0.005$;
Table 4). The lowest levels of absorbable and retained nitrogen were observed in the WRS16 animals whereas the highest - in WRS24 group. There was no effect of WRS on microbial protein synthesis $(P>0.05$; Table 4$)$. Regarding protein-related blood variables, there was no effect $(P>0.05)$ of WRS on total protein, serum urea and albumin concentrations (Table 5). However, for the lipids variables, the WRS linearly increased serum HDL and total cholesterol $(P=0.004$ and $P=0.001$, respectively; Table 5).

Table 3. Ruminal fermentation in Nelore steers fed diets with increasing level of whole raw soyabean

\begin{tabular}{|c|c|c|c|c|c|c|c|}
\hline \multirow{2}{*}{ Indices } & \multicolumn{4}{|l|}{$\operatorname{Diet}^{1}$} & \multirow{2}{*}{ SEM } & \multicolumn{2}{|c|}{$P$-value ${ }^{2}$} \\
\hline & WRSO & WRS8 & WRS16 & WRS24 & & $\mathrm{L}$ & Q \\
\hline pH & 6.23 & 6.35 & 6.47 & 6.31 & 0.02 & 0.07 & 0.02 \\
\hline Ammonia, $\mathrm{mg} \cdot \mathrm{dl}^{-1}$ & 36.13 & 35.24 & 29.65 & 33.23 & 0.91 & 0.03 & 0.04 \\
\hline \multicolumn{8}{|c|}{ Short-chain fatty acids, $\mathrm{mmol} \cdot \mathrm{I}^{-1}$} \\
\hline acetate & 66.81 & 62.79 & 64.74 & 65.04 & 0.62 & 0.467 & 0.020 \\
\hline propionate & 22.81 & 21.94 & 21.92 & 22.53 & 0.35 & 0.700 & 0.179 \\
\hline butyrate & 10.66 & 9.81 & 10.81 & 10.93 & 0.16 & 0.120 & 0.190 \\
\hline acetate:propionate & 3.04 & 3.02 & 3.11 & 3.13 & 0.03 & 0.234 & 0.923 \\
\hline total & 100.24 & 94.55 & 97.45 & 98.46 & 1.03 & 0.786 & 0.030 \\
\hline
\end{tabular}

${ }^{1}$ see Table $1 ;{ }^{2}$ see Table 2; SEM - standard error of mean

Table 4. Nitrogen balance and microbial protein synthesis in Nelore steers fed diets with increasing level of whole raw soyabean

\begin{tabular}{|c|c|c|c|c|c|c|c|}
\hline \multirow{2}{*}{ Indices } & \multicolumn{4}{|l|}{$\underline{\text { Diet }^{1}}$} & \multirow{2}{*}{ SEM } & \multicolumn{2}{|c|}{$P$-value ${ }^{2}$} \\
\hline & WRSO & WRS8 & WRS16 & WRS24 & & $\mathrm{L}$ & Q \\
\hline Total nitrogen intake, $\mathrm{g} \cdot \mathrm{d}^{-1}$ & 192.13 & 180.82 & 164.83 & 209.64 & 3.12 & 0.200 & 0.020 \\
\hline \multicolumn{8}{|l|}{ Output, $g \cdot d^{-1}$} \\
\hline faeces & 54.43 & 60.84 & 54.42 & 51.23 & 2.34 & 0.564 & 0.123 \\
\hline urine & 70.74 & 72.52 & 77.87 & 80.92 & 1.89 & 0.032 & 0.340 \\
\hline total & 125.14 & 133.35 & 132.26 & 132.17 & 2.59 & 0.087 & 0.754 \\
\hline \multicolumn{8}{|l|}{ Nitrogen balance, $g \cdot d^{-1}$} \\
\hline absorbable & 137.6 & 120.8 & 110.5 & 158.4 & 3.78 & 0.123 & 0.006 \\
\hline retained & 66.9 & 47.5 & 32.6 & 77.5 & 1.08 & 0.076 & 0.005 \\
\hline Microbial protein synthesis, $g \cdot d^{-1}$ & 319 & 326.5 & 248.3 & 299.9 & 2.65 & 0.459 & 0.652 \\
\hline
\end{tabular}

${ }^{1}$ see Table $1 ;{ }^{2}$ see Table 2 ; SEM - standard error of mean

Table 5. Blood profile of Nelore steers fed diets with increasing level of whole raw soyabean

\begin{tabular}{|c|c|c|c|c|c|c|c|}
\hline \multirow{2}{*}{ Indices } & \multicolumn{4}{|l|}{ Diet $^{1}$} & \multirow{2}{*}{ SEM } & \multicolumn{2}{|c|}{$P$-value ${ }^{2}$} \\
\hline & WRSO & WRS8 & WRS16 & WRS24 & & $\mathrm{L}$ & $Q$ \\
\hline \multicolumn{8}{|l|}{$\mathrm{mg} \cdot \mathrm{dl}^{-1}$} \\
\hline glucose & 86.24 & 83.63 & 85.12 & 79.56 & 2.19 & 0.360 & 0.740 \\
\hline total cholesterol & 306 & 323 & 342 & 347 & 6.60 & 0.001 & 0.368 \\
\hline HDL-cholesterol & 83.56 & 86.75 & 97.23 & 105.66 & 3.40 & 0.004 & 0.087 \\
\hline urea nitrogen & 25.96 & 24.97 & 24.67 & 24.70 & 0.70 & 0.695 & 0.662 \\
\hline \multicolumn{8}{|l|}{$\mathrm{g} \cdot \mathrm{l}^{-1}$} \\
\hline total protein & 5.56 & 5.45 & 5.67 & 5.65 & 0.09 & 0.264 & 0.603 \\
\hline albumin & 2.44 & 2.36 & 2.45 & 2.46 & 0.02 & 0.714 & 0.725 \\
\hline
\end{tabular}

${ }^{1}$ see Table $1 ;{ }^{2}$ see Table 2; SEM - standard error of mean 


\section{Discussion}

Whole raw soyabeans (WRS) contain in average $190 \mathrm{~g} \cdot \mathrm{kg}^{-1}$ of fat and $392 \mathrm{~g} \cdot \mathrm{kg}^{-1}$ of CP and can be used as an energy and protein source (NRC, 2001). Thus, according to the literature, WRS may partially replace ground maize and other protein sources, such as soyabean meal and urea (Barletta et al., 2016; Ventureli et al., 2015; de Almeida et al., 2016). Due to the increasing level of WRS in experimental diets, the contents of ground maize, soyabean meal and urea decreased. In some diets, the soyabean meal (WRS16 and WRS24) and urea (WRS24) inclusions were not necessary to achieve the energy, undegraded protein and degraded protein requirements (NRC, 2000). The linear decrease in DMI can be partially explained by the high EE content in WRS24 diet compared to the control (6.4 vs 2.0, respectively).

Despite the decreased DMI, the EE intake increased linearly because of the WRS EE content. Allen (2000) reported that the mechanism of feed intake depression because of the supplemental fat is not clear, and the effects of fat in ruminal fermentation, gut motility, acceptability of diets, release of gut hormones and oxidation of fat in the liver are only speculated. According to Allen et al. (2009) the oxidation of fuels, as FA in the liver, affects feed intake by transmitting the information to the central nervous system via hepatic vagal afferents. The steers fed WRS probably had limited DMI because of the higher energy density of the experimental diets in comparison to the control. Furthermore, the passage rate of feed in the rumen is an important variable to determine the digestive flow through the digestive tract. Bettero et al. (2013) reported that increasing level of fat in the diet could reduce the passage rate of nutrients and consequently may decrease DMI, as observed in the present study.

Similar results were reported by Barletta et al. (2016) who found a decrease in DMI and an increase in $\mathrm{EE}$ intakes in comparison to control group in the study on dairy cows fed $240 \mathrm{~g} \cdot \mathrm{kg}^{-1}$ of WRS per day. This was explained by the fact that in diets that contained from 50 to $60 \mathrm{~g} \cdot \mathrm{kg}^{-1}$ of EE in DM, the addition of seed oil and partially hydrogenated FA reduces intake (NRC, 2001). The kinetics of fibre in the gastrointestinal tract can be affected by the increase in the FA-chain unsaturation level due to decreased passage rate and DMI (Ueda et al., 2003). Generally, negative effects of polyunsaturated FA on fibre digestion in beef cattle are reported (Jenkins and Bridges, 2007), which is directly associated with DM digestibility (NRC, 2000). Contrary to expectations, in the present study, there was found a quadratic effect on $\mathrm{CP}$ intake, which could be explained by animal diet selection. The results obtained for the DM and nutrient digestibility, especially regarding the NDF and EE digestibility, may be linked to the type of FA that is predominant in soyabeans. Unsaturated FA from oilseeds are slowly released into the rumen, providing small amounts of lipids in the ruminal environment, which may result in rapid biohydrogenation. Thus, as it is clearly reflected by the results of the present study, the addition of WRS to the diet can be beneficial when using maize silage as a roughage source (it does not decrease fibre digestion). According to the ruminal $\mathrm{pH}$ results, it is possible to explain that the greater amounts of total SCFAs in the control diet kept the ruminal $\mathrm{pH}$ lower than in the experimental diets. However, all values were close to the average normal values, from 5.9 to 7.0, optimizing the rate of ruminal fermentation and fibre degradation.

The reduction in rumen ammonia production is usually associated with a reduction in amino acids degradation (Jalč et al., 2006). The ammonia concentrations could represent a balance between feed protein degradation and ammonia uptake for microbial protein synthesis. The presence of nitrogen compounds and ammonia in the ruminal fluid are essential for rumen microorganisms, especially for cellulolytic bacteria that use ammonia for microbial protein synthesis. However, the decreased ammonia levels in the diet with $160 \mathrm{~g} \cdot \mathrm{kg}^{-1}$ of WRS caused no change in the fibre fermentation, showing that all diets provided enough ammonia for the microorganism fermentation. The high concentration of unsaturated FAs present in WRS and the decrease in nonfibre carbohydrate as WRS was included in the diets may have contributed to the SCFA fermentation pattern in the rumen. Unsaturated FAs are toxic to many species of rumen bacteria, particularly those that are involved in fibre digestion. Nevertheless, no direct effect of lipids on the bacteria has been shown, based on SCFA results, but the quadratic effect was observed for acetic acid and the total concentration of SCFAs, with the greater value for the control diet in both cases and the lowest score for WRS8. This effect can be attributed to the decrease of NFC and increase of NDF in the diet as WRS was included. Howlett et al. (2003) fed steers diets with $15 \%$ and $25 \%$ soyabeans inclusions on a DM diet and reported changes in SCFA production. The inclusion of $25 \%$ soyabeans increased propionate and butyrate but decreased acetic acid. The authors explained those effects as a result of replacing the maize with oilseed source in the diet. 
The greater nitrogen excretion by urine due to the WRS inclusion can be explained by the higher percentage of degradable ruminal protein in the diet with $240 \mathrm{~g} \cdot \mathrm{kg}^{-1}$ of grain (Barletta et al., 2012). Despite the diets having the same protein level, the soyabean contains large amounts of degradable rumen protein, which possibly contributed to the linear increase in nitrogen excretion. In addition, the increase in soyabeans in the diets led to considerable increase in rumen ammonia; however, this did not increase the microbial protein synthesis, though there was consequently an increased excretion of this nitrogen by urine (Børsting et al., 2003).

The amount of nitrogen absorbed by the duodenum and the amount of nitrogen retained can be affected by several factors, such as content and solubility of the protein, nitrogen sources from endogenous origins, amount of digestible organic matter in the diet, treatment of the dietary protein subjected before feeding and nitrogen by rumen absorption as ammonia (Yan et al., 2006). The highest content of glycerol and degradable protein in the rumen, with increasing level of WRS in the diets influenced positively the retention and absorption of nitrogen, probably because of the better synchronisation between carbohydrate and protein provided by the diet with $240 \mathrm{~g} \cdot \mathrm{kg}^{-1}$ of grain.

Spanghero and Kowalski (1997) using a regression analysis showed that nitrogen balance was positively correlated with dietary nitrogen availability, and suggested an overestimation of retained nitrogen with an increase in dietary nitrogen availability as a consequence. In the present study it is implied that greater nitrogen intake in animals fed WRS0 and WRS24 diets and higher metabolizable protein by greater rumen undergradable protein in animals fed WRS24 diet could result in higher amounts of nitrogen retained. In addition, the same authors confirmed the general knowledge that nitrogen balance is overestimated in dairy cows, probably because of volatile nitrogen losses from samples (faeces and urine, milk nitrogen), dermal and scurf losses and so limited analysis of nitrogen from other compounds (nitrite/ nitrate).

Microbial efficiency is a function of microbial growth and substrate available for fermentation in the rumen. The composition and substrate fermentation rate are factors related to rumen while microbial flow is related to particle size and the volume and rate passage in the rumen. The predominant limitation to microbial synthesis factor is usually the concentration of non-fibre carbohydrates in the diet (Demeyer and Van Nevel, 1986).
In the present study, there was no change in microbial nitrogen production when steers were fed diets containing WRS. It has been established that microbial nitrogen produced in the rumen and flowing to the duodenum is related to the total amount of organic matter fermenting in the rumen (Nennich et al., 2005). HDL and total cholesterol resulted from the increase in EE in the WRS diets, which contributed significantly to the metabolism of these metabolites and consequently increase cholesterol blood concentration (Barletta et al., 2012).

\section{Conclusions}

Whole raw soyabean inclusion into the diets of Nelore steers does not change nutrients digestibility and promotes few changes in rumen metabolism and blood parameters. However its addition has no detrimental effect on digestive functions.

\section{Acknowledgements}

The authors would like to thank FAPESP (Process No. 2010/03979-0) and CNPq for the financial support for this work.

\section{References}

Agrianual, 2016. Yearbook of the Brazilian Agriculture. FNP Consulting and Trade, São Paulo (Brazil)

Allen M.S., 2000. Effects of diet on short-term regulation of feed intake by lactating dairy cattle. J. Dairy Sci. $83,1598-1624$, https:// doi.org/10.3168/jds.S0022-0302(00)75030-2

Allen M.S., Bradford B.J., Oba M., 2009. Board invited review: The hepatic oxidation theory of the control of feed intake and its application to ruminants. J. Anim. Sci. 87, 3317-3334, https:// doi.org/10.2527/jas.2009-1779

AOAC International, 2000. Official Methods of Analysis of AOAC International. $17^{\text {th }}$ Edition. Gaithersburg, MD (USA)

Barletta R.V., Gandra J.R., Freitas Junior J.E., Verdurico L.C., Mingoti R.D., Bettero V.P., Benevento B.C., Vilela F.G., Rennó F.P., 2016. High levels of whole raw soya beans in dairy cow diets: digestibility and animal performance. J. Anim. Physiol. Anim. Nutr. 100, 1179-1190, https://doi.org/10.1111/jpn.12406

Barletta R.V., Rennó F.P., Gandra J.R., Freitas Jr. J.E., Verdurico L.C., Mingoti R.D., Villela F.G., 2012. Blood parameters and performance of dairy cows fed with whole raw soyabean. Arch. Zootec. 61, 483-492

Bettero V.P., Gandra J.R., Nunes H.V.N., Freitas Jr. J.E., Barletta R.V., Carvalho M.V., Detmann E., Pereira J.C., 2013. Sources of omega- 6 fatty acids do not alter the rumen degradation and transit of fibre from dairy cow diets. J. Anim. Feed Sci. 22, 295-301, https://doi.org/10.22358/jafs/65916/2013

Børsting C.F., Kristensen T., Misciattelli L., Hvelplund T., Weisbjerg M.R., 2003. Reducing nitrogen surplus from dairy farms. Effects of feeding and management. Livest. Prod. Sci. 83, 165-178, https://doi.org/10.1016/S0301-6226(03)00099-X 
Casali A.O., Detmann E., Valadares Filho S.C., Pereira J.C., Henriques L.T., de Freitas S.G., Paulino M.F., 2008. Influence of incubation time and particles size on content of indigestible compounds in feed and feces of bovines obtained by in situ procedures. Rev. Bras. Zootec. 37, 335-342, https://doi. org/10.1590/S1516-35982008000200021

Chen X.B., Gomes M.J., 1992. Estimation of microbial protein supply to sheep and cattle based on urinary excretion of purine derivatives - an overview of technical details. International Feed Resources Unit. Rowett Research Institute. Aberdeen (Scotland)

Chizotti M.L., Valadares Filho S.C., Valadares R.F.D., Chizotti F.H.M., Tedeschi L.O., 2008. Determination of creatinine excretion and evaluation of spot urine sampling in Holstein cattle. Livest. Sci. 113, 218-225, https://doi.org/10.1016/j.livsci.2007.03.013

deAlmeida G.F., Del Valle T.A., de Paiva P.G., de Jesus E.F., Barletta R.V., Gandra J.R., Bettero V.B., Takiya C.S., Rennó F.P., 2016. Effects of whole raw soybean or whole cottonseed on milk yield and composition, digestibility, ruminal fermentation and blood metabolites of lactating dairy cows. Anim. Prod. Sci. 57, 122128, https://doi.org/10.1071/AN15266

Demeyer D., Van Nevel C., 1986. Influence of substrate and microbial interaction on efficiency of rumen microbial growth. Reprod. Nutr. Dev. 26, 161-170, https://doi.org/10.1051/rnd:19860203

Erwin E.S., Marco G.J., Emery E.M., 1961. Volatile fatty acid analyses of blood and rumen fluid by gas chromatography. J. Dairy Sci. 44, 1768-1771, https://doi.org/10.3168/jds.S00220302(61)89956-6

Folch J., Lees M., Sloane Stanley G.H., 1957. A simple method for the isolation and purification of total lipids from animal tissues. J. Biol. Chem. 226, 497-509

Foldager J., 1977. Protein requirement and non-protein nitrogen for high producing cow in early lactation. PhD Thesis. Michigan State University, East Lansing, Ml (USA)

Howlett C.M., Vanzant E.S., Anderson L.H., Burris W.R., Fieser B.G., Bapst R.F., 2003. Effect of supplemental nutrient source on heifer growth and reproductive performance, and on utilization of corn silage-based diets by beef steers. J. Anim. Sci. 81, 2367-2378, https://doi.org/10.2527/2003.8192367x

Jalč D., Potkański A., Szumacher-Strabel M., Kowalczyk J., Cieślak A., 2006. The effect of a high concentrate diet and different fat sources on rumen fermentation in vitro. J. Anim. Feed Sci. 15, Suppl. 1., 137-140, https://doi.org/10.22358/jafs/70162/2006

Jenkins T.C., 1993. Lipid metabolism in the rumen. J. Dairy Sci. 76, 38513863, https://doi.org/10.3168/jds.S0022-0302(93)77727-9

Jenkins T.C., Bridges W.C. Jr., 2007. Protection of fatty acids against ruminal biohydrogenation in cattle. Eur. J. Lipid Sci. Technol. 109, 778-789, https://doi.org/10.1002/ejt.200700022

Kramer J.K.G., Fellner V., Dugan M.E.R., Sauer F.D., Mossoba M.M., Yurawecz M.P., 1997. Evaluating acid and base catalysts in the methylation of milk and rumen fatty acids with special emphasis on conjugated dienes and total trans fatty acids. Lipids 32, 1219-1228, https://doi.org/10.1007/s11745-997-0156-3
Nennich T.D., Harrison J.H., VanWieringen L.M., Meyer D., Heinrichs A.J., Weiss W.P., St-Pierre N.R., Kincaid R.L., Davidson D.L., Block E., 2005. Prediction of manure and nutrient excretion from dairy cattle. J. Dairy Sci. 88, 3721-3733, https://doi.org/10.3168/jds.S0022-0302(05)73058-7

NRC, 2000. Nutrient Requirements of Beef Cattle. $7^{\text {th }}$ Revised Edition. Update 2000. The National Academics Press. Washington, DC (USA), https://doi.org/10.17226/9791

NRC, 2001. Nutrient Requirements of Dairy Cattle. $7^{\text {th }}$ Revised Edition. The National Academics Press. Washington, DC (USA), https://doi.org/10.17226/9825

Spanghero M., Kowalski Z.M., 1997. Critical analysis of N balance experiments with lactating cows. Livest. Prod. Sci. 52, 113-122, https://doi.org/10.1016/S0301-6226(97)00138-3

Rennó L.N., Valadares Filho S.C., Valadares R.F.D., Paulino M.F., Rennó F.P., Silva P.A., 2008. Urea levels in diet for steers of four genetic groups: microbial protein production by the urinary purine derivatives, using two collection methodologies. Rev. Bras. Zootec. 37, 546-555, https://doi.org/10.1590/ S1516-35982008000300021

Ueda K., Ferlay A., Chabrot J., Loor J.J., Chilliard Y., Doreau M., 2003. Effect of linseed oil supplementation on ruminal digestion in dairy cows fed diets with different forage:concentrate ratios. J. Dairy Sci. 86, 3999-4007, https://doi.org/10.3168/jds. S0022-0302(03)74011-9

Valadares Filho S.C., Magalhães K.A., Rocha Junior V.R., 2006. Brazilian Beef Cattle Food Composition Tables. UFV. Viçosa, MG (Brazil)

Valadares R.F.D., Broderick G.A., Valadares Filho S.C., Clayton M.K., 1999. Effect of replacing alfalfa with high moisture corn on ruminal protein synthesis estimated from excretion of total purine derivatives. J. Dairy Sci. 82, 2686-2696, https://doi. org/10.3168/jds.S0022-0302(99)75525-6

Van Soest P.J., Robertson J.B., Lewis B.A., 1991. Methods for dietary fiber, neutral detergent fiber, and nonstarch polysaccharides in relation to animal nutrition. J. Dairy Sci. 74, 3583-3597, https://doi.org/10.3168/jds.S0022-0302(91)78551-2

Venturelli B.C., de Freitas Júnior J.E., Takiya C.S., Araújo A.P.C., Santos M.C.B., Calomeni G.D., Gardinal R., Vendramini T.H.A., Rennó F.P., 2015. Total tract nutrient digestion and milk fatty acid profile of dairy cows fed diets containing different levels of whole raw soybeans. J. Anim. Physiol. Anim. Nutr. 99, 1149-1160, https://doi.org/10.1111/jpn.12297

Yan T., Frost J.P., Agnew R.E., Binnie R.C., Mayne C.S., 2006. Relationships among manure nitrogen output and dietary and animal factors in lactating dairy cows. J. Dairy Sci. 89, 3981-3991, https://doi.org/10.3168/jds.S0022-0302(06)72441-9 